\title{
Using Creative Educational Drama to Enhance Self-Development Skills for the Students at University Level
}

\author{
Hisham Saad Zaghloul \\ Department of Self Development Skills, Deanship of Preparatory Year \& Supportive Studies, \\ Northern Border University, Saudi Arabia \\ Department of Educational Media, Faculty of Specific Education, Mansoura University, Egypt
}

\begin{abstract}
This study has been undertaken using a creative drama in teaching in order to improve the communication and thinking skills for the students of preparatory year students at the Northern Border University. It aimed to measure the differences between the experimental and control groups in skills acquisition among students. The study was conducted on 140 students from both genders (males=70 and females=70). The students were divided into four groups: each has 35 students. The study adopted an experimental approach by observing students' behavior through affecting their communication and thinking skills with using drama. The findings confirmed that using drama in teaching significantly affected on the experimental group than the students of the control group who were taught with traditional methods as the experimental group achieved better results than the control group. Furthermore, the study stressed the possibility of benefiting from the drama in teaching other practical courses at the university level and provided several recommendations in this regard as well.
\end{abstract}

Keywords-Creative drama; creative educational drama; selfdevelopment skills; communication skills; thinking skills

\section{INTRODUCTION}

Creative drama is one of the most effective tools for improving communication and thinking skills. The use of creative drama technique in the classroom is a studentcentered, in which learning process results in the development of the students of any curriculum. Creative drama method of teaching helps learners develop and improve their divergent thinking skills, creativity, communication and it matures their oral and written communication skills. The use of creative drama enriches the students' imagination and willingness to act or pretend as a means of reinforcing academic, emotional, and interpersonal objectives [1]. In fact, creative drama shows the learners the way to be appreciated and understand about others' the needs which will make the student themselves able to form a value judgment. Drama activities can reflect positively on the student's behavior and his personality as well. Many previous studies have confirmed the effectiveness, creative drama as an effective method of teaching in the preuniversity educational stages and several courses. The approach of creative drama leads students to discover their inner strengths of "knowing" into concrete action.

Further, according to the theorists, teachers can use creative dramatics to support social, academic, personal and interpersonal goals. This emphasizes the use of learners' imaginative skill and intelligence to help them learn through their own activity and practices because learners process information differently from the highly matured students. The concept of creative dramatics also supports the growth of their language and vocabulary while stimulating high-level cognitive processes.

Therefore, it is worth saying that using creative drama for educational purposes has been the purpose of many studies that have undertaken with interactive drama techniques to facilitate the following: curriculum, language acquisition, and skills acquisition. Lastly, most of these studies have focused on pre-college education stage. Classroom exercises based on creative drama can provide a genuine experience and also fun in the classroom and guide learners to become aware of the use of their imagination. Therefore, this study will investigate the effectiveness of using drama and its impact on the learning and teaching process of self-development courses including communication and thinking skills.

\section{LITERATURE REVIEW}

Multiple studies have been conducted investigating the use of creative drama as a teaching method. The objective of this study is to investigate the degree to which improvement in communication and thinking skills is effective when using drama pedagogically. Author in [2] classifies thinking skills as crucial self-development skills. It is through thinking that students interpret and process the information they receive. Master the skill of collecting relevant information and formulate conclusions as a basis for decision making. Author in [3] states that exposing students to creative drama provokes a change in their thought patterns, enhancing their curiosity, driving them towards new discoveries, and further learning opportunities. Moreover, Çokadar and Y1lmaz [4] investigated the use of creative drama and found that the participation, interaction, and harmony which emerges as part of the creative drama process, greatly enhance science students' understanding of environmental concepts, positively direct them to develop their learning. According to [5], the creative drama is an effective teaching method for use when teaching students at all stages of formal education. Indeed, reflecting on the potential value of creative drama, Kay [6] recommended that universities increase the number of training sessions in 
how to use creative drama in the classroom, introducing it as a fun and student-centered method to adopt when teaching.

Bayraktar and Okvuran [7] investigated the utility of creative drama and indicated that it motivates students to develop self-reflection and creative thinking skills, which can be developed alongside their writing skills, as part of their basic education. Espousing an alternative perspective, Partab [8] suggested that the primary value of drama in education is that it provides entertainment and psychological support, reducing student's anxiety. Moreover, he claimed that creative drama can develop community awareness, providing greater comprehension of learners' problems.

Similarly examining the social aspect of using drama in the classroom, Aydeniz, and Ozcelik [9] reported that the use of drama enhances students' communication skills, benefitting group discussions and eliminating shyness. Moreover, they noted that drama creates an opportunity for students to express themselves clearly, consequently improving their level of academic achievement. Aykac's [10] study further supported the view that creative drama improves students' ability to express themselves, observing that it can enhance their selfconfidence by bestowing a capacity to communicate effectively, and thus creates an inner satisfaction within individuals.

The most recent study was that conducted by [11]. This study discovered that drama activities could positively influence pupils' skills acquisition; in particular fueling selfexpression and self-confidence. Moreover, creative drama can be utilized to teach languages, mathematics, social studies, and music, as well as to develop sensory and motor skills.

\section{RESEARCH QUESTIONS}

The present study seeks to answer the following main question:

- What is the effectiveness of an educational program based on creative drama to develop communication and thinking skills among male and female students of the preparatory year at the Northern Border University?

- The following sub-questions are derived from the main question:

○ Is there a significant effect from "gender" type of communication and thinking skills?

○ Is there a significant effect from "teaching Method (Traditional method \& Creative drama)" on communication and thinking skills?

○ Is there any interaction between "gender" and "teaching Method (Traditional method \& Creative drama)" and the level of communication and thinking skills?

\section{SigNIFICANCE OF THE STUdY}

The importance of the study lies in the fact that it is an attempt to:

- It draws the attention to the effectiveness of using drama in developing student's communication and thinking skills.
- It may provide teachers with applicable teaching situations using creative drama.

- It may provide results, which may be applicable to other topics.

- It may provide a clear impression of thinking and communication skills course designed to include drama with these courses as an effective method.

\section{OBJEctives OF THE STUdy}

The study seeks to explore the following objectives:

- To Design an educational program for creative drama (trainer's guide) in the field of communication and thinking skills for students in the preparatory year at Northern Border University.

- To measure the effectiveness of the creative drama program proposed in the development of communication and thinking skills of the students.

- To discover if there is any significant difference between the communication and thinking skills between the male and female students.

\section{DIMENSIONS OF THE STUDY}

- Academic dimension

This study focused on the effectiveness of drama as an educational method compared to the traditional method of teaching both communication and thinking skills.

- Human dimension

The study is concerned with students studying in the preparatory year at Northern Borders University, Arar, Saudi Arabia.

- Time dimension

The study was conducted within the first term of the academic year for $2017-2018$.

- Place dimension

This study was carried out in the preparatory year of Northern Borders University targeting its students from both genders.

\section{DEFINITION OF TERMS USED IN THE STUDY}

It is important to define and explain the basic terms in any study, especially when there is difficulty in understanding these terms or when they carry more than one meaning. Thus, these terms are defined below:

- Creative Drama: The innovative positions that the teacher of the course to participate with the learner in the classroom teaching and rely on innovative attitudes and the realization of the mind and open the door to debate and dialogue and raise questions that enrich the practical aspect of the courses, which the study codified to serve the practical objectives of communication and thinking skills. 
- Educational Creative Drama: It is the main study instrument and teacher's guide to transforming the scientific material of the communication and thinking skills of dramatic acting situations between the course instructor and students and between students and themselves and their colleagues as well in order to transform the theoretical material into practical characteristics of education.

- Self-development skills: These are the skills required for students of the preparatory year in their first years of university and summed up in communication and thinking skills.

- Communication Skills: A general course for students of the preparatory year, aim at activating the human communication of the student inside and outside the university community to get him a good citizen who benefits himself and his family and society.

- Thinking Skills: A compulsory course taught to the students of the preparatory year, aims to support them with the positive thinking patterns, accept others, build ideas and to make decisions, and deal with a range of other skills through brainstorming sessions and creative thinking based on student participation in the classroom.

\section{Methodology}

\section{A. Design of the Study}

A research design aims to provide a framework for data collection and analysis procedures [12]. The choice of a research design is "based on the nature of the research problem or issue being addressed, the researchers' personal experiences, and the audiences for the study" [13]. Thus, the present study employed the quasi-experimental method to investigate the effectiveness of self-development course using drama among preparatory year male and female students on their thinking and communication skills.

\section{B. Instrument}

For the purpose of the study, a structured observation was used. The observation strategy considered as a valuable strategy because it provides evidence of what happens in the classroom [14]. Moreover, Observation can provide a researcher with a rich description of the situation under investigation [15]. Thus, observation technique used in this study in order to assess any changes may occur in the behavior of the students in the experimental group during a specified period of studying the self-development courses (communication skills and thinking skills). The observation form was divided into two main sections: communication skills and thinking skills. Each of this skill was divided into three sub-sections. The course instructor of each group assesses the changes, which may occur in the period of experiment and record that for each student of his/her group. All the assessments of the observation were recorded on a five-point Likert scale, offering five choices: 1) poor; 2) acceptable; 3) good; 4) very good; and 5) excellent (see Appendix 1).

\section{Procedures}

The researcher adopted the following procedures:

- Review of related literature and related previous studies.

- Several dramatic teaching scenes were conducted in the light of using drama for each lesson in both courses (communication skills and thinking skills) for about five weeks.

- Research instrument (only observation card) was adopted upon a review of the literature and related studies, which paved the way for the researcher to greatly benefits from these studies to construct observation card content to suit the study objectives.

- Validity and reliability of the instrument have been measured.

- Assigning sample of the study and apply the pre-test of using drama for both control and experimental groups.

- The control group was taught using the traditional way of teaching, whereas the experimental group was taught using drama.

- The post-test of using drama was supplied by the end of teaching the assigned unit.

- Data were statistically analyzed using the software SPSS to discover if there are any significant differences.

- Results have been discovered and discussed.

- Based on the results, the recommendations and suggestions have been given.

\section{Data Analysis}

The experimental study data was analyzed by using SPSS program, version 22 to answer the research questions. The researcher used mainly analytical tests in the study. The first one was a t-test in order to determine the significant differences between the study variables and the impact of creative drama on the student's communication and thinking skills. Additionally, the t-test has been used to discover the results of the paired sample test for the experimental group in the case of Pre-test and Post-test in communication skills, thinking skills and their dimensions on the students. The study referred to significant differences based on the p-value. Moreover, the researcher used two-way ANOVA in order to show interaction effects between the selected variables and the communication and thinking skills.

\section{RESULTS AND DisCUSSION}

This study proved that using creative drama in the instruction of certain developing learning skills affect the achievement level of self-department skills students in a positive way. The results were clear through changes that occurred in the student's behavior in the classroom while learning. 
TABLE I. DESCRIPTIVE StATISTICS OF RESEARCH GROUP’s SCORES IN COMMUNICATION SKILLS AND THINKING SKILLS

\begin{tabular}{|c|c|c|c|c|c|c|c|c|}
\hline \multicolumn{5}{|c|}{ Statistical variable } & \multirow{2}{*}{$\mathbf{N}$} & \multirow{2}{*}{ M } & \multirow{2}{*}{ SD } & \multirow{2}{*}{ Variance } \\
\hline Variables & Tools & Respondent & Group & Test & & & & \\
\hline \multirow{8}{*}{ 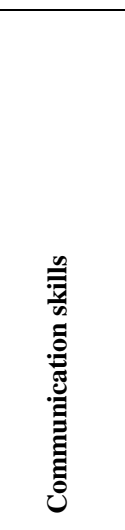 } & \multirow{8}{*}{ 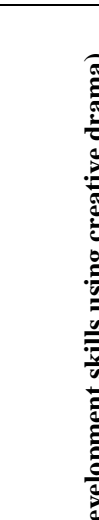 } & \multirow[b]{4}{*}{ 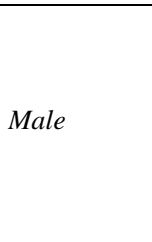 } & \multirow{2}{*}{ Experimental Group } & Pre-test & 35 & 23.1429 & 2.11636 & 4.479 \\
\hline & & & & Post-test & 35 & 46.8000 & 1.99706 & 3.988 \\
\hline & & & \multirow{2}{*}{ Control Group } & Pre-test & 35 & 21.2857 & 2.38342 & 5.681 \\
\hline & & & & Post-test & 35 & 23.4286 & 2.47678 & 6.134 \\
\hline & & \multirow{4}{*}{ Female } & \multirow{2}{*}{ Experimental Group } & Pre-test & 35 & 46.3429 & 1.86205 & 3.467 \\
\hline & & & & Post-test & 35 & 46.8000 & 1.89116 & 3.576 \\
\hline & & & \multirow{2}{*}{ Control Group } & Pre-test & 35 & 23.8286 & 1.90179 & 3.617 \\
\hline & & & & Post-test & 35 & 22.9714 & 2.51450 & 6.323 \\
\hline \multirow{10}{*}{ 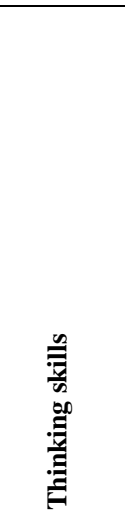 } & تِ & \multirow{5}{*}{ Male } & \multirow{3}{*}{ Experimental Group } & Pre-test & 35 & 22.9429 & 2.31292 & 5.350 \\
\hline & 岕 & & & & 35 & 466286 & & 3005 \\
\hline & $\vec{E}$ & & & Post-test & 35 & 46.6286 & & 3.005 \\
\hline & 节 & & \multirow{2}{*}{ Control Group } & Pre-test & 35 & 22.9429 & 2.31292 & 5.350 \\
\hline & है & & & Post-test & 35 & 23.1714 & 2.38236 & 5.676 \\
\hline & 篓 & \multirow{5}{*}{ Female } & \multirow{2}{*}{ Experimental Group } & Pre-test & 35 & 22.6000 & 2.30345 & 5.306 \\
\hline & ฮี & & & Post-test & 35 & 22.9714 & 2.60639 & 6.793 \\
\hline & 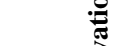 & & \multirow{3}{*}{ Control Group } & Pre-test & 35 & 23.4000 & 3.77453 & 14.247 \\
\hline & 离 & & & Post-test & 35 & 248571 & 227703 & 5185 \\
\hline & $\overrightarrow{0}$ & & & Post-test & 35 & $24.85 / 1$ & 2.27103 & 5.185 \\
\hline
\end{tabular}

According to Table I, there is a statistically meaningful difference between the two groups: control groups and experimental groups, as was clear from the score averages for the t-test, which shows a significant difference between the two groups. Moreover, a significant difference between males and females was apparent in every group. The statistics showed higher post-test values after the experiment, between both the male and female groups; these results were found after the majority of sessions of the experiment. These exceptional values, as apparent from Table I, show the positive influence of creative drama on both communication skills and thinking, confirming the value of using creative drama sessions to improve students' self-development.

The significant values obtained included the pre and posttest scores for the experimental group and encompassed all variables. Benefits of using drama as a teaching approach were apparent for both genders; the variance value for males was (5.681) before using creative drama and (6.134) after. Similarly, improvements were noted for females; before using the dramatic method, their skills acquisition was (3.617) and after it rose to (6.323). Moreover, the study confirmed that verbal communication skills were the most significantly improved skills; although non-verbal skills, thinking skills, problem-solving skills and brainstorming skills were also enhanced.

These significant values included the pre and post-test scores for the experimental group. These values illustrated statically in all research based on variables. These significant values showed significant differences in Verbal Comm. Skills $(\mathrm{t}=8.168 ; \mathrm{p}=$. 014), Non- Verbal Communication $(\mathrm{t}=$ 11.065; $\mathrm{p}=0.000)$, Electronic Communication $(\mathrm{t}=-11.469 ; \mathrm{p}$ $=$. 055), Total Communication Skills $(\mathrm{t}=11.233 ; \mathrm{p}=.000)$, Critical Thinking Skills $(\mathrm{t}=11.374 ; \mathrm{p}=0.000)$, Problem Solving Skills $(\mathrm{t}=13.729 ; \mathrm{p}=.000)$, Brainstorming Skills $(\mathrm{t}=$ 9.655; $\mathrm{p}=.000)$, Total thinking skills $(\mathrm{t}=12.141 ; \mathrm{p}=.000)$, this result reflects the effectiveness of creative drama on all research variables, see Table II. The result of the study regarding its significant impact on the learning process and development of the student's characteristics and behaviors accorded with all studies stated in the literature review of this study. For example, Aydeniz, \& Ozcelik, [9], Aykac [10], Sengul [11] which confirmed the constructive role of using suing drama in a learning process which agreed with this study results. 


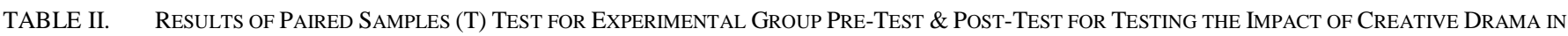
COMMUNICATION \& THINKING SKILLS

\begin{tabular}{|c|c|c|c|c|c|c|c|c|c|}
\hline \multirow{3}{*}{\multicolumn{2}{|c|}{$\begin{array}{l}\text { Variables } \\
\text { (Measurements) }\end{array}$}} & \multicolumn{5}{|c|}{ Paired Differences } & \multirow{4}{*}{$\begin{array}{l}\mathbf{t} \\
8.168\end{array}$} & \multirow{4}{*}{$\begin{array}{l}\text { DF } \\
139\end{array}$} & \multirow{4}{*}{$\begin{array}{l}\text { Sig. } \\
.000\end{array}$} \\
\hline & & \multirow{3}{*}{$\begin{array}{l}\text { Mean } \\
2.77857\end{array}$} & \multirow{3}{*}{$\begin{array}{l}\text { SD } \\
4.02522\end{array}$} & \multirow{3}{*}{$\begin{array}{l}\begin{array}{l}\text { Std. } \\
\text { Error }\end{array} \\
.34019\end{array}$} & \multicolumn{2}{|c|}{ 95\% Confidence } & & & \\
\hline & & & & & \multirow{2}{*}{$\begin{array}{l}\text { Lower } \\
2.10595\end{array}$} & \multirow{2}{*}{$\begin{array}{l}\text { Upper } \\
3.45119\end{array}$} & & & \\
\hline Pair 1 & $\begin{array}{l}\text { Verbal Comm. Skills Pre-test } \\
\text { Verbal Comm. Skills Post-test }\end{array}$ & & & & & & & & \\
\hline Pair 2 & $\begin{array}{l}\text { Non- Verbal Comm. Skills Pre-test } \\
\text { Nonverbal Comm. Skills Post-test }\end{array}$ & 3.51429 & 3.75794 & .31760 & 2.88633 & 4.14224 & 11.065 & 139 & .000 \\
\hline Pair 3 & $\begin{array}{l}\text { Electronic Comm. Skills Pre-test } \\
\text { Electronic Comm. Skills Post-test }\end{array}$ & 5.99286 & 6.18247 & .52251 & 4.95975 & 7.02596 & 11.469 & 139 & .000 \\
\hline Pair 4 & $\begin{array}{l}\text { Critical Thinking Skills Pre-test } \\
\text { Critical Thinking Skills Post-test }\end{array}$ & 3.36429 & 3.49966 & .29578 & 2.77949 & 3.94909 & 11.374 & 139 & .000 \\
\hline Pair 5 & $\begin{array}{l}\text { Problem Solving Skills Pre-test } \\
\text { Problem Solving Skills Post-test }\end{array}$ & 3.78571 & 3.26258 & .27574 & 3.24053 & 4.33090 & 13.729 & 139 & .000 \\
\hline Pair 6 & $\begin{array}{l}\text { Brainstorming Skills Pre-test } \\
\text { Brainstorming Skills Post-test }\end{array}$ & 4.63571 & 5.68123 & .48015 & 3.68637 & 5.58506 & 9.655 & 139 & .000 \\
\hline Pair 7 & $\begin{array}{l}\text { Total communication Skills Pre- } \\
\text { test } \\
\text { Total communication Skills Post- } \\
\text { test }\end{array}$ & $1.22857 \mathrm{E} 1$ & 12.9405 & 1.09367 & 10.1233 & 14.4481 & 11.233 & 139 & .000 \\
\hline Pair 8 & $\begin{array}{l}\text { Total thinking skills Pre-test } \\
\text { Total thinking skills Post-test }\end{array}$ & 1.17857E1 & 11.4858 & .97073 & 9.86640 & 13.7050 & 12.141 & 139 & .000 \\
\hline
\end{tabular}

Moreover, as in Table II, it is noteworthy that the study shed light on the impact of creative drama on the study variables: gender, teaching method (whether traditional or using creative drama), and the interaction between gender and the teaching method. Here, we used the probability value, statistically termed the p-value, to discover significant differences between communication skills and thinking skills, after using drama as a teaching method. The study demonstrated that the gender has no significant effect on communication skills, as the p-value for gender (male and female) is (0.547). Meanwhile, an effect of gender emerged in relation to thinking skills, where the p-value for gender was
(0.049). However, this effect is considered small; because the partial eta squared, the value is (0.028). However, the figures for the type of teaching method were clearly different; the results confirmed that teaching method has a clear impact on both communication (sig. 000) and thinking skills (sig. 000) after applying an ANOVA analysis for this variance. Finally, the study concluded by noting a moderate interaction between gender and teaching method and thinking skills and communication skills; this was apparent from the p-values for both skills, which were (547) and (0.006) respectively. For more statistical details and $\mathrm{p}$ values in both situations, see Tables III and IV below.

TABLE III. RESUlts OF 2WAY ANOVA TEST FOR THE IMPACT OF CREATIVE Drama ON TOTAL (COMMUNICATION SKILLS) OF THE EXPERIMENTAL GROUP

\begin{tabular}{|c|c|c|c|c|c|c|c|}
\hline \multicolumn{8}{|l|}{ Tests of Between-Subjects Effects } \\
\hline \multicolumn{8}{|c|}{ Dependent Variable: Total (Communication Skills) Post-test } \\
\hline Source & $\begin{array}{l}\text { Type III Sum of } \\
\text { Squares }\end{array}$ & Def & Mean Square & $\mathbf{F}$ & Sig. & $\begin{array}{l}\text { Partial Eta } \\
\text { Squared }\end{array}$ & Effect size \\
\hline Corrected Model & $19497.257 \mathrm{a}$ & 3 & 6499.086 & $1.298 \mathrm{E} 3$ & .000 & .966 & Large \\
\hline Intercept & 171500.000 & 1 & 171500.00 & $3.426 \mathrm{E} 4$ & .000 & .996 & Large \\
\hline Gender (male\& female) & 1.829 & 1 & 1.829 & .365 & .547 & .003 & Small \\
\hline $\begin{array}{l}\text { Method (Traditional method \& Creative } \\
\text { drama) }\end{array}$ & 19493.600 & 1 & 19493.600 & $3.894 \mathrm{E} 3$ & .000 & .966 & Large \\
\hline Gender * method & 1.829 & 1 & 1.829 & .365 & .547 & .003 & Small \\
\hline Error & 680.743 & 136 & 5.005 & & & & \\
\hline Total & 191678.000 & 140 & & & & & \\
\hline Corrected Total & 20178.000 & 139 & & & & & \\
\hline \multicolumn{4}{|l|}{ a. R Squared =. 966 (Adjusted R Squared =. 966) } & & & & \\
\hline
\end{tabular}


TABLE IV. RESUlts of 2WAY ANOVA TEST FOR THE IMPACT OF CREATIVE DRAMA ON TOTAL (THINKING SKILLS) OF THE EXPERIMENTAL GROUP

\begin{tabular}{|c|c|c|c|c|c|c|c|}
\hline \multicolumn{8}{|c|}{$\begin{array}{l}\text { Tests of Between-Subjects Effects } \\
\text { Dependent Variable: Total (Thinking Skills) Post-test }\end{array}$} \\
\hline Source & $\begin{array}{l}\text { Type III Sum of } \\
\text { Squares }\end{array}$ & Def & Mean Square & $\mathbf{F}$ & Sig. & $\begin{array}{l}\text { Partial Eta } \\
\text { Squared }\end{array}$ & Effect size \\
\hline Corrected Model & $17724.936 a$ & 3 & 5908.312 & $1.364 \mathrm{E} 3$ & .000 & .968 & Large \\
\hline Intercept & 173958.750 & 1 & 173958.750 & $4.015 \mathrm{E} 4$ & .000 & .997 & Large \\
\hline Gender (male\& female) & 17.150 & 1 & 17.150 & 3.958 & .049 & .028 & Small \\
\hline $\begin{array}{l}\text { Method (Traditional method \& } \\
\text { Creative drama) }\end{array}$ & 17673.779 & 1 & 17673.779 & $4.079 \mathrm{E} 3$ & .000 & .968 & Large \\
\hline Gender * method & 34.007 & 1 & 34.007 & 7.848 & .006 & .055 & Small \\
\hline Error & 589.314 & 136 & 4.333 & & & & \\
\hline Total & 192273.000 & 140 & & & & & \\
\hline Corrected Total & 18314.250 & 139 & & & & & \\
\hline \multicolumn{4}{|c|}{ a. R Squared =. 968 (Adjusted R Squared =. 967) } & & & & \\
\hline
\end{tabular}

\section{CONCLUSION}

The purpose of carrying out this study is to investigate the effectiveness of the drama on the students' self- development, which focused on the effect of drama on both communication and thinking skills among Saudi students studying at the preparatory level in Northern Borders University. The target population of this study was targeting both genders (males and females) in the deanship of preparatory year and supportive studies of Northern Borders University for the academic year, 2017-2018. The present study discovered a number of findings in this context. The study showed that using drama in the educational situation plays a constructive role in the learning process through improving the student's skills. Besides, the significant effect was clearer of the experimental group than the students of the control group who were taught with traditional methods. Moreover, the study also showed the effectiveness of creative drama on the self-development of the students, which were clear on the impact of communication skills and thinking skills of the students in their courses. The high values of post-test for both of male and female groups in the experimental group confirmed the fundamental role of using drama developing the learning process and students' behavior.

\section{- Limitations of the present study}

This study, like all studies, has limitations. The study conducted only on one academic institute namely, the Northern Borders University in Saudi Arabia, where the researcher works as lecturer and head of self-development department in it. Consequently, this may make the study's scope is limited and its results cannot be generalized to other students in other Saudi academic institutions. Furthermore, the study did not employ more research methods for data collection such as interviews, questionnaire, etc., because the students were not happy to participate in the study includes more research methods, due to the pressure they face it in their study. Moreover, there is no more time for the researcher for designing other research methods. Additionally, there is no easy access to the female students to make interviews with them due to the segregation systems between males and females in Saudi universities.

\section{RECOMMENDATIONS AND SUGGESTIONS}

Based on the findings of the study, the following recommendations and suggestions are made:

- Creative drama courses should be taught as main part of the curriculum of self-development skills to be a more effective teaching tool.

- Creative drama method should be progressively used as a teaching method in other courses as well.

- Longitudinal studies should be conducted to identify the effect of creative drama in teaching and learning communication and thinking skills

- Other studies need to investigate the changes, which occur for students, who are taught by the teachers that have increased communication and thinking skills due to being introduced to creative drama.

- More qualitative studies are recommended to be conducted to investigate the effects of drama education in more depth as well.

\section{ACKNOWLEDGMENT}

The author gratefully acknowledges the approval and the support of this research study by the grant no. (EAR-2017-47-F-6931) from the Deanship of Scientific Research at Northern Border University, Arar, K.S.A.

\section{REFERENCES}

[1] Froese, V. (1996). Whole-language: Practice and Theory (2nd Ed.). Needham, MA: Allyn and Bacon.

[2] Bayley, R. (2002). Thinking skills in the early years. Gifted Education International, 16(3), 248-260. doi:10.4324/9780203410851

[3] Karakelle, S. (2009). Enhancing fluent and flexible thinking through the creative drama process. Thinking Skills and Creativity, 4 (2), 124-129. doi:10.1016/j.tsc.2009.05.002

[4] Çokadar, H., \& Yılmaz, G. C. (2010). Teaching Ecosystems and Matter Cycles with Creative Drama Activities. Journal of Science Education and Technology, 19 (1), 80-89. doi:10.1007/s10956-009-9181-3

[5] Adıgüzel, H. Ö, \& Timuçin, E. (2010). The effect of creative drama on student achievement in the instruction of some development and learning theories. Procedia - Social and Behavioral Sciences, 9, 17411746. doi:10.1016/j.sbspro.2010.12.393 
[6] Kay, N. B. (2010). Examination on self-efficacy of the pre-service teachers of the classroom teacher and pre-school teacher according to creative drama method. Procedia - Social and Behavioral Sciences, 2(2), 4533-4539. doi:10.1016/j.sbspro.2010.03.726

[7] Bayraktar, A., \& Okvuran, A. (2012). Improving Students Writing Through Creative Drama. Procedia - Social and Behavioral Sciences, 51, 662-665. doi:10.1016/j.sbspro.2012.08.220

[8] Partab, V. (2012). Creative Healing-An Examination of the Value of Creative Drama in Helping South African Children Deal with the Traumas of Their Lives. Procedia - Social and Behavioral Sciences, 69, 487-491. doi:10.1016/j.sbspro.2012.11.437

[9] Aydeniz, H., \& Ozcelik, N. (2012). Impact of Creative Drama Method on the French Achievement of University Students. Procedia - Social and Behavioral Sciences, 47, 962-967. doi:10.1016/j.sbspro.2012.06.764
[10] Aykac, M. (2013). The effect of creative drama activities on the personal development of housewives. Educational Research and Reviews, 8 (21), 2130.

[11] Sengul, O. A. (2016). The Views of the Pre-service Teachers about the Creative Drama as a Method Used in Primary Schools. Universal Journal of Educational Research, 4 (5), 1244-1251. doi:10.13189/ujer.2016.040539

[12] Bryman, A. (2008). Social research methods. (3rd ed.). Oxford: Oxford University Press.

[13] Creswell, J. W. (2009). Research design: qualitative, quantitative and mixed methods approach. 3rd ed. London: Sage.

[14] Borg, S. (2006). Teacher Cognition and Language Education: Research and Practice. London: Continuum.

[15] Cohen, L., Manion, L. \& Morrison, K. (2007). Research Methods in Education. 6th ed. London: Routledge.

\section{APPENDIX 1}

\section{SELF-DEVELOPMENT SKILLS EVALUATION OBSERVATION FORM}

- Name of the Rapporteur (optional):

- Course (Communication / Thinking Skills):

- Observation Group (Male / Female):

:

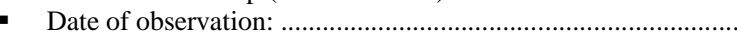

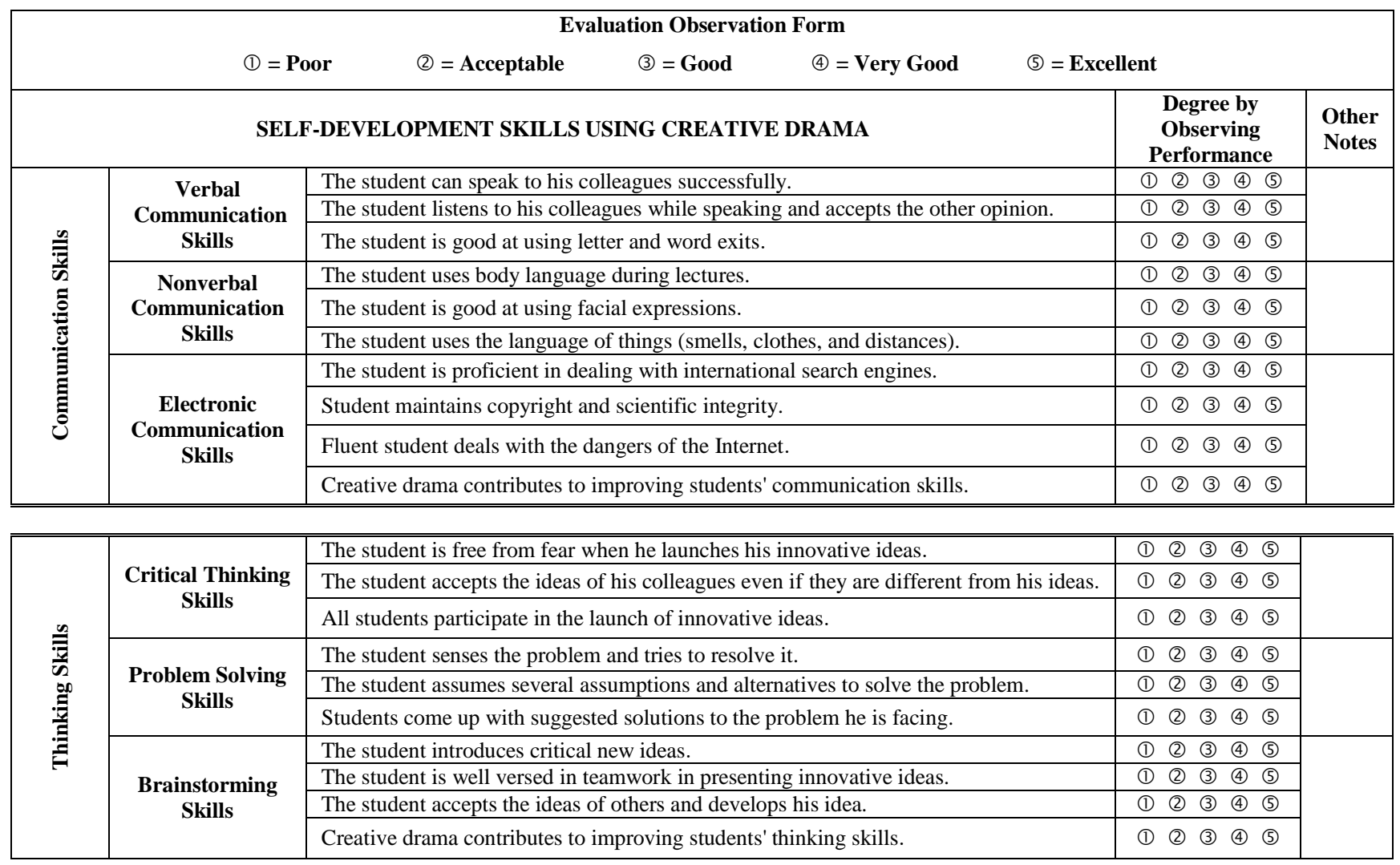

